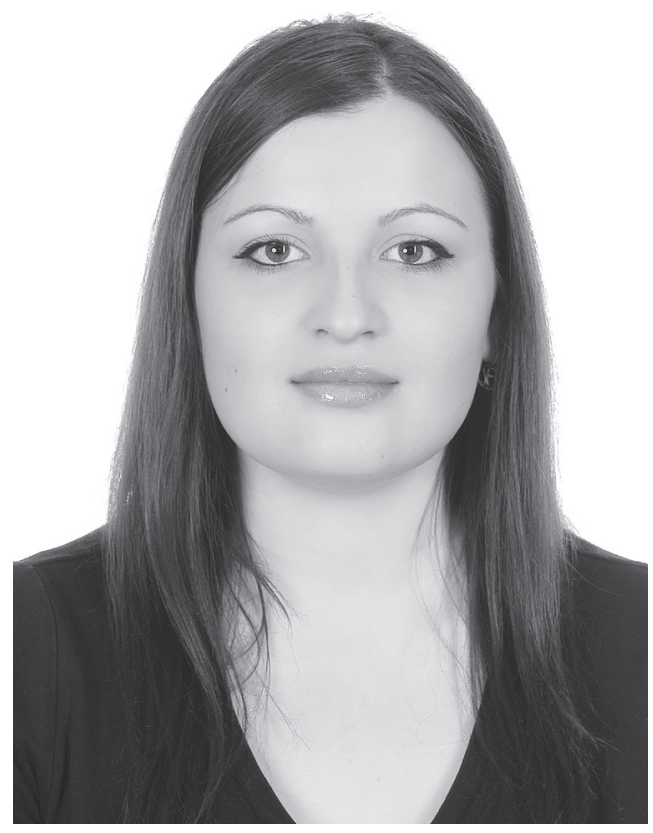
мии государственного управления при Президенте Украины, 03057, г. Киев, вул. Антона Цедика, 20, тел.: +380 (96) 62532 78, e-mail: alina.brendak@gmail.com

ORCID: 0000-0002-0204-5216

DOI: $10.32689 / 2414-0562-2018-15-5-52-63$

\title{
PROSPECTS OF DECENTRALIZED CONTROL IMPLEMENTATION IN THE AREA OF STATE CUSTOMS AFFAIRS OF UKRAINE
}

Abstract. One of the priorities of building an effective system of public administration in Ukraine is the reform in the area of state customs affairs. Approval of Ukrainian Customs Code renewed edition in 2012 was an important step forward in brining national customs control system to the best international standards. Nevertheless practice shows that since then new threats and challenges in this area have appeared, due to some gaps in legislation and absence of effective mechanisms to manage customs sector.

Considering mentioned, in this article analysis of core elements of decentralized control in the area of state customs affairs is conducted. This approach requires separation of two main processes: process of decision making and process of customs formalities fulfillment. On the one hand this will help to involve as many experts as needed for better decision making during customs control, on the other hand such system is expected to contribute into integrity issues. 
On practice such process may be put into place through establishing of front and back offices. Front offices will be in contact with economic operators in case if needed, and back offices will play leading role in the process of decision making. Core issue is that front and back offices should be geographically located in different regions and some decisions on one customs declaration based on risk analysis and assessment may be taken by experts located in different customs offices (e.g. customs value is checked in one office and non-tariff regulation in another one).

During prospects of decentralized control implementation in the area of state customs affairs of Ukraine identification it is stressed that some changes have to be done. Such changes have to be made ranging from customs organizational structure review to legislation improvement. The author argues, that integrated implementation of such approach will help to improve efficiency of state customs affairs management and to ensure fundamentally new level of state customs security.

Keywords: state customs affairs, decentralized customs control, customs clearance, customs formalities, risk management system, risks analysis and assessment, front and back offices.

\section{ПЕРСПЕКТИВИ ЗАПРОВАДЖЕННЯ ДЕЦЕНТРАЛІЗОВАНОГО КОНТРОЛЮ В ДЕРЖАВНІЙ МИТНІЙ СПРАВІ УКРАЇНИ}

Анотація. Одним із пріоритетних напрямів розбудови ефективної системи публічного управління в Україні є реформування державної митної справи. Затвердження оновленої редакції Митного кодексу України в 2012 році стало важливим кроком уперед у приведенні національної системи митного контролю до найкращих міжнародних стандартів. Однак практика свідчить, що з того часу у цій сфері відносин з'явилися нові загрози та виклики, пов'язані, зокрема, із наявністю прогалин у законодавстві та відсутністю дієвих механізмів управління митним сектором.

У зв'язку із зазначеним у статті проаналізовано ключові аспекти організації децентралізованого контролю в сфері державної митної справи. Це передбачає розділення двох основних процесів: процесу прийняття управлінських рішень та процесу виконання митних формальностей. 3 одного боку, це допоможе залучити якомога більше експертів, що є необхідною умовою для більш зваженого прийняття управлінських рішень під час здійснення митного контролю, з іншого, - такий підхід, як очікується, сприятиме доброчесності.

На практиці цей підхід може бути реалізований шляхом створення фронт- та бек-офісів на базі існуючих митниць. Фронт-офіси контактуватимуть у разі потреби з економічними операторами, а бек-офіси відіграватимуть провідну роль у процесі прийняття управлінських рішень. Основна ідея полягає в тому, що фронт- та бек-офіси мають бути розташовані в різних регіонах, а окремі рішення щодо однієї митної декларації, що базуються на аналізі та оцінці ризиків, можуть прийматись фахівцями, які територіально знаходяться у різних митницях (наприклад, митна вартість перевіряється в одному офісі, а нетарифне регулювання - в іншому). 
При визначенні перспектив запровадження децентралізованого контролю в державній митній справі України акцентується на необхідності здійснення ряду змін, починаючи від перегляду організаційної структури митниць і закінчуючи вдосконаленням нормативно-правової бази. Комплексне впровадження такого підходу дасть можливість підвищити ефективність управління державною митною справою та забезпечити принципово новий рівень митної безпеки країни.

Ключові слова: державна митна справа, децентралізований митний контроль, митне оформлення, митні формальності, система управління ризиками, аналіз та оцінка ризиків, фронт- та бек-офіси.

\section{ПЕРСПЕКТИВЫ ВНЕДРЕНИЯ ДЕЦЕНТРАЛИЗОВАННОГО КОНТРОЛЯ В ГОСУДАРСТВЕННОМ ТАМОЖЕННОМ ДЕЛЕ УКРАИНЫ}

Аннотация. Одним из приоритетных направлений построения эффективной системы публичного управления в Украине является реформирование государственного таможенного дела. Принятие обновленной редакции Таможенного кодекса Украины в 2012 году стало важным шагом вперед в рамках внедрения в национальную систему таможенного контроля лучших международных стандартов. Тем не менее, практика свидетельствует о том, что с тех пор в этой сфере появились новые угрозы и вызовы, связанные, в частности, с наличием пробелов в законодательстве и отсутствием действенных механизмов управления таможенным сектором.

В связи с этим в статье проведен анализ ключевых аспектов организации децентрализованного контроля в сфере государственного таможенного дела. Это предусматривает разделение двух основных процессов: процесса принятия управленческих решений и процесса выполнения таможенных формальностей. С одной стороны, это поможет привлечь как можно больше экспертов для более взвешенного принятия управленческих решений, с другой - такой подход, как ожидается, будет способствовать добропорядочности.

На практике такой процесс может быть реализован путем создания фронти бэк-офисов. Фронт-офисы будут поддерживать контакты с экономическими операторами в случае необходимости, а бэк-офисы будут играть ведущую роль в процессе принятия управленческих решений. Основной идеей является то, что фронт- и бэк-офисы должны располагаться в разных регионах, а некоторые решения по одной таможенной декларации, основанные на анализе и оценке рисков, смогут приниматься экспертами, которые территориально находятся в разных таможенных органах (например, таможенная стоимость проверяется в одном офисе, а нетарифное регулирование - в другом).

При определении перспектив внедрения децентрализованного контроля в таможенном деле Украины акцентируется на необходимости осуществления ряда изменений, начиная с пересмотра организационной структуры таможен и заканчивая улучшением нормативно-правовой базы. По мнению автора, комплексное внедрение такого подхода позволит повысить эффективность 
управления государственным таможенным делом и обеспечить принципиально новый уровень таможенной безопасности Украины.

Ключевые слова: государственное таможенное дело, децентрализированный таможенный контроль, таможенное оформление, таможенные формальности, система управления рисками, анализ и оценка рисков, фронт- и бэк-офисы.

Target setting. Capabilities to ensure state customs security largely depends on using mechanisms of selective customs control. Application of modern risk-management technologies in this area helps to mitigate human factor when making relevant decisions and brings a vast improvement to quality of public administration in state customs affairs. Thus, according to international requirements and standards each country has to ensure the best possible balance between simplification of customs formalities and sufficient customs control.

Unfortunately, current approaches to organization of customs control of goods and vehicles in Ukraine can't solve issues of effective selective control to the full extent. Customs clearance, which is performed by one customs officer, and time limits for customs formalities fulfillment, which are established by the law, do not contribute into quality and efficiency of customs control improvement. This also prevents from ensuring adequate level of state customs interests security according to the competence of customs authorities. Ukraine has made a great mistake when launched selective customs control, based on application of risk management system, and haven't ensured effective application of other elements, which compensate possibility of skipping customs formalities upon crossing the border by goods and vehicles (authorized economic operators, post-clearance control, customs audit etc.).

Remediation of current situation is not only about implementation of mentioned mechanisms, but also about significant improvement of basic model of selective customs control organization. This makes actual tasks of identification and implementation of tools to optimize customs control.

Analysis of basic research and publication. Implementation of risk based selective customs control is subject to researches of many Ukrainian and foreign scientists. The most comprehensive description of Ukrainian risk management system is given in joint monograph "Risk management in customs: foreign experience and domestic practice" under general editorship of Berezhnuk I. [1] Authors of this paper focus their attention on customs risks analysis and assessment during customs control, legal aspects of customs risk management system application, finding some steps to improve existing system. At the same time, possible scenarios of risk based customs procedures review have been studied partly and specific tools of decentralized customs 
control implementation haven't been studied at all.

The object of this article is analysis of core issues of decentralized customs control organization, prospects identification and working out the most appropriate approach to its implementation in the area of state customs affairs considering threats and weaknesses in both internal and external customs environment of Ukraine.

The statement of basic materials. Article 320 of Ukrainian Customs Code, states that customs control should be selective and based on risk management system application. At the same time, part one of the Article 318 of Ukrainian Customs Code stipulates that all goods and commercial purpose vehicles, which cross the border of Ukraine are subjects to customs control. [2] This means that regardless fulfillment of additional customs formalities regarding goods and vehicles, which are based on results of risk management system application, supervisory control of other foreign economic transactions has to be applied. Currently, regardless results of risks analysis and assessment customs officer should check each customs declaration submitted to clear goods. Thus, according to the Instruction on customs formalities fulfillment during customs clearance of goods with a use of customs declaration in the form of single administrative document, approved by the order of the Ministry of Finance of Ukraine № 631 dated 30.05.2012, process of customs formalities fulfillment by each declaration consists of the following steps:

1. registration (checking format, recording date and time by assignment registration number to customs decla- ration and other documents (if needed), and transferring all information to the database);

2. initial check (checking submission of invoice or document, which contains information on value, automatic check of filling customs declaration correctness according to the requirements of customs legislation, matching electronic and hard copy of customs declaration (if there is hard one));

3 . acceptance of declaration for customs clearance by stamping it (putting stamps on hard copies or electronically depending on type of submitted declaration);

4. denying to clear goods by the customs declaration (occurs on this stage when customs declaration is missing some data or is submitted without documents on customs value, which are required by the law; electronic customs declaration is missing some requisites required by the law; or customs declaration is submitted in violation of other requirements, established by the Customs Code of Ukraine);

5. customs clearance, which means fulfillment of the following customs formalities:

5.1. checking compliance with a deadlines of declaration submission (if such deadlines are established by the law);

5.2. checking marks on completion of goods movement (if such cases specified by customs legislation);

5.3. comparison control (comparison of authorized bank requisites, currency rates, checking if there are any existing (not expired) sanctions applied to economic operator(s) according to the Law of Ukraine on foreign economic activity; checking if there were any denials in 
customs clearance of the goods; checking compliance with prohibitions and restrictions requirements, established by the legislation, considering information from consent documents, provided electronically by other authorities; checking customs duties and other payments; considering information from foreign customs authorities and law enforcement agencies);

5.4. control, performed with application of risk management system, including risks analysis by automated risk management system (ARMS);

5.5. tariff classification control;

5.6. country of origin control;

5.7. non-tariff measures control;

5.8. tax exemptions control;

5.9. IPR control;

5.10. customs value control;

6. suspending of customs clearance (in cases when there is a need for more detailed IPR or non-food products check according to the law);

7. handing over declaration to the specialized division (according to the law in complicated cases or by demand of such division);

8. physical inspection (if needed);

9. accomplishment of customs clearance;

10. regardless other customs formalities goods may be subject to customs audit [3].

Consequently, today we have a system, when each customs declaration has to be fully checked as for the possibility of breach Ukrainian customs law, including application of ARMS. This seems quite consistent considering absence of other efficient mechanisms to control foreign economic transactions before and after customs clearance of goods and vehicles. At the same time, if to take into account that such control has to be performed by single customs officer and during not more than 4 hours, situations starts to be seen in a new light. Such approach puts customs officers under pressure of choice: whether to check information accurately and possibly fail 4-hours deadline, or just to carry out sort analysis of information and clear goods as soon as possible. Anyway in such cases thoughts about securing state interests are not key factors during decision-making. This boosts corruption risks, at the same time security of customs interests rapidly decreases.

Improvement of existing system may be achieved by different ways. This may be wider application of customs audit and its strengthening, introduction of post-clearance control and automatic release of goods, further automation of risks analysis and assessment, including capabilities in different types of border crossing points and before arrival of goods [1, 283$285]$ etc. But in this article we are going to explore decentralized approach to customs control, which can help to enhance control before and upon arrival of goods to the customs territory of Ukraine. At the same moment it allows to involve as many customs officers as needed in control of foreign trade transaction, who may work on customs declaration simultaneously.

In order to implement decentralized system of customs control first of all out-of-date organization charts of regional customs offices should be reviewed. At the moment there are 27 regional customs offices. Typical structure of customs office consists of the following units [4]: 
- customs posts (detached offices for customs clearance);

- customs control organization;

- customs duties administration;

- counteracting customs offences and international cooperation;

- risk management;

- information technologies (IT);

- customs statistics;

- human resources (HR);

- prevention and exposure of corruption;

- protection of state secrets and cryptographic security of information;

- financial support and infrastructure;

- finance, accounting and reporting;

- legal affairs;

- dealing with resorts of citizens and granting access to public information.

In case of decentralized approach launching regional customs structure becomes less important but specialization comes into the picture. Decentralized system requires establishment of front- and back-offices and functioning of so called physical inspections groups.

Customs officers in back-offices will make final decision on list of customs formalities, which are to be fulfilled in each particular case, based on risks analysis and assessment, including application of ARMS.

Customs officers in front-offices will make customs clearance itself and perform documentary control, if such formalities are assigned by back-office.

Customs officers involved into work of physical inspections groups will make physical inspection of goods, vehicles,
X-ray scanning, dog handling, weighing, sampling etc.

To implement such approach all customs declarations should be submitted in a centralized way to one server. Once declaration is submitted it is transferred to one of the back-offices according to its specialization (depending on type of goods) or randomly. Customs officer in back-office performs risks analysis and assessment of customs declaration, including ARMS application, and compilates final list of binding customs formalities, which are to be fulfilled. In complicated cases or if there is a need to involve some subject matter expert customs officer in back-office may assign special status to the declaration and it will be transferred to relevant unit or expert for providing recommendations or making decisions. Afterwards customs officer transmits customs declaration in the mode of customs clearance.

Once declaration is in mode of customs clearance it is automatically sent to the front-office, which is picked up in a random automated way (for documentary control, in case if such formalities are assigned by back-office, and customs clearance itself) and to physical inspections group, which works in customs office/place where goods are physically located (for physical inspection and other intrusive forms of customs control, if such formalities are assigned by back-office).

Customs officers from front-offices and physical inspections groups may initiate additional customs formalities and expand list, assigned by back-office, but they can't cancel any formalities from the list.

Customs officer from front-office can clear goods only after entering results of 
all customs formalities, including physical inspection and other intrusive forms of control, performed by physical inspections group (if there were any).

Moreover, customs officer from back-office may apply procedure when customs clearance can be finalized by front-office only after verification of customs control results in back-office.

List of customs formalities, which includes substantiations and additional explanations for each customs formality, information on initiator (this information is hidden but kept in database: ARMS recommendations or ID of the customs officer, who added customs formality to the list), and results of their fulfillment are recorded into database and are subjects to further analysis of effectiveness and efficiency. This information can be also used for personal assessment and financial motivation of best customs officers.

In order to make this system work properly specialization of customs officers in back-offices is needed. List of standard specialization areas should be defined. Specialization, on the one hand, should be quite narrow (it should be possible for customs officer to acquire necessary competency and knowledge for carrying-out further risks analysis and assessment in specific area), but on the other one - quite vast (to avoid cases when customs officers of one specialization form small group which may go into cahoots).

Customs officers will be able to broaden their specializations by going through special trainings and passing relevant tests. Training for customs officers should be quite practical. They should learn technological and pricing characteristics of specific goods, coun- tries of origin, manufacturers, typical routes, market places, illegal modus operandi etc.

In fact specializations may be areas of control (tariff classification, country of origin, non-tariff measures, IPR, customs value etc.) and people working today in relevant units of regional customs offices may be offered to pass through the process of specialization assigning to become part of back-offices.

Apart of back-offices specialization, customs officers from front-offices and physical inspections groups should go through practical trainings considering specifics of their work as well.

Customs officer in back-office will be picked-up randomly considering his/ her specialization and type of goods and the only condition is that this officer is not located in customs office, where goods are physically located. Customs officer in front-office will be picked-up randomly and the condition is that this officer is not located in customs office, where goods are physically located, and/or in customs office, where backoffice, which performed risks analysis and assessment, located. Physical inspection (if it's assigned) will be performed by group of customs post, where goods are physically located.

For instance, goods are delivered to one of the customs posts of Lviv Customs Office as it's close to the border, importer, which is located in Dnipro, submits declaration to the central customs server. According to the specialization and random selection this declaration is transmitted to Kyiv backoffice for risks analysis and assessment. During control of goods customs officer of Kyiv back-office involves tariff classification expert, who is located 
in Mykolaiv. Afterwards customs officer of Kyiv back-office forms list of customs formalities in the system and transmits customs declaration in the mode of customs clearance. By random selection declaration appears in Sumy front-office for documentary check and customs post of Lviv Customs Office for physical inspection (as both have been assigned by back-office). All results of customs formalities fulfillment are put into the system and if everything is fine customs clearance can be finalized and goods can be released (Picture 1).

If importer doesn't want to wait there is a possibility to submit customs declaration before arrival of goods. In this case, once goods cross the border importer will be informed if there is a need to go to the customs office for physical inspection or goods can be delivered right to the premises of importer. This procedure is in place in national system of state customs affairs at the moment.

On the start of the shift customs officers will register in IT-system and become available for declarations processing. All customs declarations from central server are allotted according to interregional algorithm firstly for risks analysis and assessment, including ARMS application, and, afterwards, for customs clearance and/or physical inspection. All decisions on all stages and all communications between stakeholders should be substantiated, entered and stored in IT-system. At the

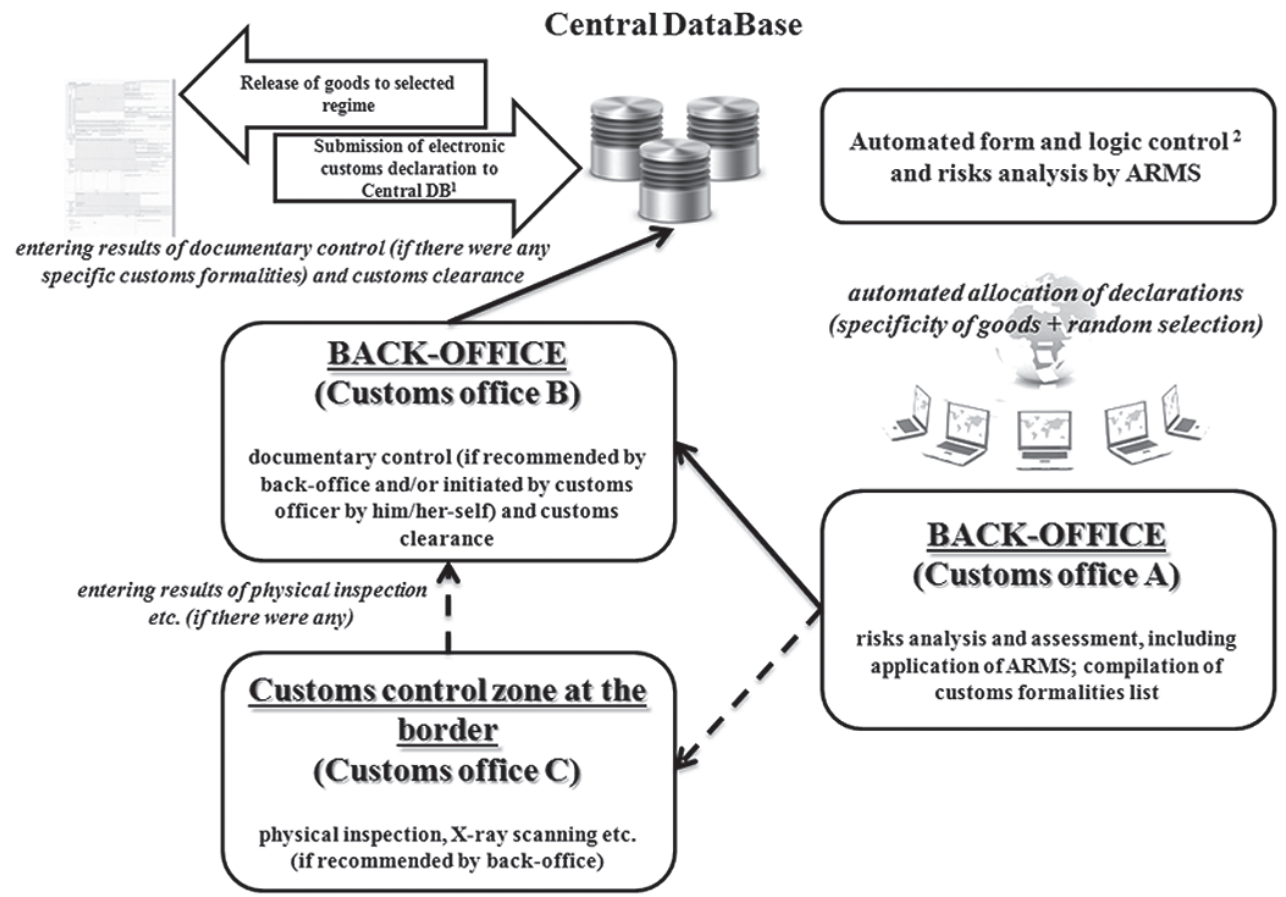

${ }^{1}$ Submission of customs declaration is done before or upon arrival of goods to the border crossing point

${ }^{2}$ Format and logical control is performed in order to exposure of errors, which make impossible acceptance of customs declaration for customs clearance

Pic. 1. Proposed algorithm of decentralized customs control of goods and vehicles in Ukraine (developed by the author) 
same time all communication should be anonymous and one customs officer should not have information about other customs officers involved into the process of customs control by declaration. All information regarding place of goods location, back- and front-offices and relevant customs offices working on customs declaration, the same as information about other customs officials, should be hidden from customs officers involved in work with declaration in order to avoid cahoots.

Implementation of decentralized customs control system is resource consumed in terms of IT system development, but it brings a lot of advantages. One of them is solving of corruption and integrity issues due to multilayered decisions making and control approach. Those people in back-offices, who make decisions on customs formalities list are interested in offences disclosure, at the same time they won't overburden customs offices in front-offices or physical inspection groups with fruitless customs formalities.

To ensure fulfillment of above mentioned tasks structure of customs offices has to be reviewed. Structure of customs should be transformed to tackle abovementioned issues. Infrastructure along the border should be able to handle goods and vehicles, including cargo terminals equipped with technical means of customs control where goods may be physically inspected or where importer may just wait for final decision on release of goods. Inside the country customs officers working in specific units (tariff classification, country of origin, non-tariff measures, IPR, customs value etc.) may become experts of back-offices and customs officers work- ing at customs posts may start working in front-offices. Back-offices may be even virtual and involve experts, who are located in different regions, but successfully have passed process of specialization assignment. Also, it is important to ensure work of customs audit teams, which will be able to perform customs control on premises of economic operators after goods are released. Subjects to customs audits as well as post-clearance control may be identified by back-offices too. The system of decentralized customs control should be completed with divisions of counteracting customs offences, which will be transformed in rapid-response units with enforcement functions.

Conclusions. Key characteristics of decentralized system of customs control are multilayered approach, geographic distance and anonymity, which will reduce influence of human factor of each individual customs officer, who makes decision on necessity of customs formalities fulfillment, fulfils such formalities and puts results into a system. This system seems to be quite adequate to Ukrainian realities and can bring a vast improvement in the area of anticorruption activities. Corruption is a very serious threat for efficient functioning of inner customs environment, it also has a negative influence on customs perception in society (external aspect). Weak point in implementation of decentralization in the area of customs control may be absence of customs officers' motivation. They have passed through many attempts to reform customs system and lost their faith in positive changes in the system. This situation has to be solved through appropriate funding and salaries level. 
Additionally, efforts have to be made in order to improve image of customs officers through vast outreach on results of implementation new transparent approach to customs control of goods and vehicles. Non-financial motivation, which will be based on respect, advocacy and support of customs officers should be essential part of new decentralized system implementation.

It is argued, that implementation of such approach can be done regardless of such progressive issues application like automated release of goods or conceptions of authorized economic operators. Thus, customs officers in back-offices may work only with customs declarations selected by results of automated risks analysis and assessment by ARMS, at the time when rest of declarations may be cleared automatically. But application of such approach is possible when post-clearance control and customs audit is in place and functions properly. Implementation of other mentioned initiatives can also strengthen new customs philosophy.

The most advanced directions of further researches regarding development of public administration system in the area of Ukrainian customs affairs the author of the article considers studying possible algorithms of cooperation between different stakeholders during risks analysis and assessment, and studying main criteria for measuring efficient and effectiveness of risk management system application during customs control.

\section{REFERENCES}

1. Berezhnuk I. G. (2014), Upravlinnia ryzykamy v mytnij spravi: zarubizh- nyj dosvid ta vitchyzniana praktyka [Risk management in customs: foreign experience and domestic practice], Melnyk A. A., Khmelnytskyi, Ukraine.

2. The Verkhovna Rada of Ukraine (2012), Customs Code of Ukraine, available at: http://zakon2.rada.gov.ua/laws/ show/4495-17/conv/print (Accessed 12 August 2018)

3. Ministry of Finance of Ukraine (2012), "Instruction on customs formalities fulfillment during customs clearance of goods with a use of customs declaration in the form of single administrative document, approved by the order of the Ministry of Finance of Ukraine № 631 dated 30.05.2012", available at: http://zakon3.rada.gov.ua/laws/show/z136012/print1511376159093920 (Accessed 18 August 2018).

4. State Fiscal Service of Ukraine (2018), "Regional authorities of the State Fiscal Service of Ukraine", available at: http://sfs.gov.ua/pro-sfs-ukraini/ struktura-/teritorialni-organi/ (Accessed 16 August 2018).

\section{СПИСОК ВИКОРИСТАНИХ ДЖЕРЕЛ}

1. Управління ризиками в митній справі: зарубіжний досвід та вітчизняна практика: монографія; за заг. ред. I. Г. Бережнюка. - Хмельницький: ПП Мельник А. А., 2014. $288 \mathrm{c}$.

2. Митний кодекс України: Закон України від 13.03.2012 р. № 4495-VI (зі змінами) // База даних "Законодавство України" / Верховна рада України. URL: http://zakon0.rada. gov.ua/laws/show/4495-17

3. Порядок виконання митних формальностей при здійсненні митного оформлення товарів із застосуванням митної декларації на бланку єдиного адміністративно- 
го документа : наказ Міністерства фінансів України від 30.05.2012 р. № 631 // База даних “Законодавство України" / Верховна рада України. URL: http://zakon2.rada.gov.ua/ laws/show/z1360-12.
4. Територіальні органи Державної фіскальної служби України // Офіційний сайт Державної фіскальної служби України. URL: http://sfs.gov. ua/pro-sfs-ukraini/struktura-/teritorialni-organi/ 